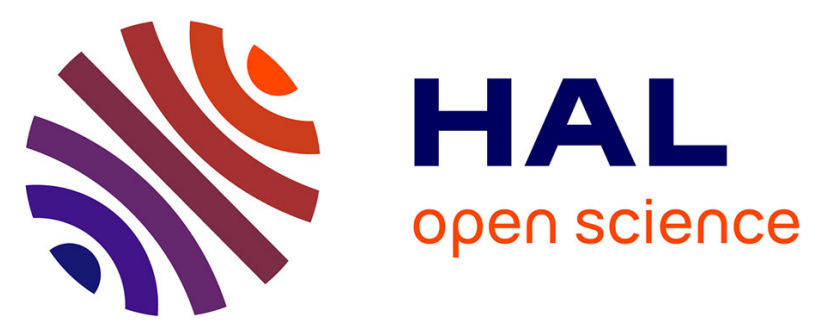

\title{
Anaerobic co-digestion of waste activated sludge and greasy sludge from flotation process: Batch versus CSTR experiments to investigate optimal design
}

R. Girault, G. Bridoux, F. Nauleau, C. Poullain, J. Buffet, P. Peu, A.G. Sadowski, F. Béline

\section{To cite this version:}

R. Girault, G. Bridoux, F. Nauleau, C. Poullain, J. Buffet, et al.. Anaerobic co-digestion of waste activated sludge and greasy sludge from flotation process: Batch versus CSTR experiments to investigate optimal design. Bioresource Technology, 2012, 105, p. 1 - p. 8 . hal-00736422

\section{HAL Id: hal-00736422 \\ https://hal.science/hal-00736422}

Submitted on 28 Sep 2012

HAL is a multi-disciplinary open access archive for the deposit and dissemination of scientific research documents, whether they are published or not. The documents may come from teaching and research institutions in France or abroad, or from public or private research centers.
L'archive ouverte pluridisciplinaire HAL, est destinée au dépôt et à la diffusion de documents scientifiques de niveau recherche, publiés ou non, émanant des établissements d'enseignement et de recherche français ou étrangers, des laboratoires publics ou privés. 
Author-produced version of the article published in Bioresource Technology, 2012, 105, 1-8. Original publication available at www.sciencedirect.com - doi:10.1016/j.biortech.2011.11.024

\title{
Anaerobic co-digestion of waste activated sludge and greasy sludge from flotation process: batch versus CSTR experiments to investigate optimal design
}

Girault R., ${ }^{\mathrm{a}, \mathrm{b}}$, Bridoux G. ${ }^{\mathrm{c}}$, Nauleau F. ${ }^{\mathrm{c}}$, Poullain C. ${ }^{\mathrm{c}}$, Buffet J., ${ }^{\mathrm{a}, \mathrm{b}}$, Peu P. ${ }^{\mathrm{a}, \mathrm{b}}$, Sadowski A.G. ${ }^{\mathrm{d}}$, Béline F. ${ }^{\mathrm{a}, \mathrm{b}}$

${ }^{a}$ Cemagref, UR GERE, 17 av. de Cucillé, CS 64427, F-35044 Rennes, France.

(Tel. (+33)2 23482142 - Fax: (+33)2 23482115 - e-mail: romain.girault@cemagref.fr)

${ }^{b}$ Université Européenne de Bretagne, F-35044 Rennes, France

c SAUR, Recherche et développement, Atlantis, 1, av. Eugène Freyssinet, F-78280 Guyancourt, France.

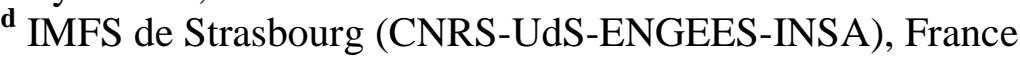

\begin{abstract}
In this study, the maximum ratio of greasy sludge to incorporate with waste activated sludge was investigated in batch and CSTR experiments. In batch experiments, inhibition occurred with a greasy sludge ratio of more than $20-30 \%$ of the feed COD. In CSTR experiments, the optimal greasy sludge ratio was $60 \%$ of the feed COD and inhibition occurred above a ratio of $80 \%$. Hence, batch experiments can predict the CSTR yield when the degradation phenomenon are additive but cannot be used to determine the maximum ratio to be used in a CSTR configuration. Additionally, when the ratio of greasy sludge increased from $0 \%$ to $60 \%$ of the feed COD, CSTR methane production increased by more than $60 \%$. When the greasy sludge ratio increased from $60 \%$ to $90 \%$ of the feed COD, the reactor yield decreased by $75 \%$.
\end{abstract}

Keywords: anaerobic digestion, waste activated sludge, DAF sludge, LCFA, inhibition 


\section{Introduction}

Sewage sludge management is one of the most expensive items in small wastewater treatment plants (WWTP < 30000 p.e.). Most small WWTPs using activated sludge technology are not equipped with a primary clarifier. As a consequence, sewage sludge from such plants is only composed of waste activated sludge (WAS). Anaerobic digestion of sewage sludge is a well-known technology which enables the volume of sludge produced to be reduced, energy to be recovered and the sludge to be stabilised. However, WAS is less biodegradable than primary sludge (Parkin \& Owen, 1986) and the biochemical methane potential (BMP) of WAS is consequently significantly lower than that of a mixture of primary and secondary sludge (Chynoweth et al., 1993; Knezevic et al., 1995). Due to the low methane potential and high building and operating costs, anaerobic digestion systems for waste activated sludge are not profitable and are thus rare in small WWTPs. Pretreatment methods can be used to optimize these processes and to increase biogas production (Appels et al., 2008; Carrere et al., 2010) but these involve the consumption of energy and/or chemicals. Another solution is co-digestion of WAS with one or several substrates with a higher BMP value (Mata-Alvarez et al., 2000; Alatriste-Mondragón et al., 2006).

Lipid-rich wastes are known to combine high biodegradability and a high BMP value. However, the degradation of such a substrate leads to the production of long chain fatty acids (LCFAs) in the digester, which may destabilise the process in different ways (Pereira et al., 2005): (1) adsorption of LCFAs onto the sludge can affect transport and the protective functions of the bacteria wall and form a hydrophobic layer of LCFAs around biomass aggregates. This phenomenon considerably reduces exchanges between the media and the "encapsulated" bacteria; (2) entrapment of LCFAs in biomass aggregates can lead to biomass flotation in the reactor and, as a consequence, to biomass leakage; (3) precipitation of the LCFAs with divalent ions such as $\mathrm{Ca}^{2+}$ or $\mathrm{Mg}^{2+}$ makes them inaccessible to anaerobic biomass and hence reduces their biodegradability. Moreover, the $\mathrm{C} / \mathrm{N}$ value of lipid-rich substrates is often above the optimal values (20-30) defined by Parkin and Owen (1986), which can lead to a lack of nutrients when an excess of this kind of substrate is used. Inhibition of anaerobic digestion by lipid-rich substrates and particularly LCFAs, caused by these phenomena has 
been reported in the literature. Many authors mention reversible inhibition of methanogenesis and other anaerobic digestion stages by LCFAs (Koster and Kramer, 1987; Angelidaki and Ahring, 1992 ; Rinzema et al. 1994; Alves et al., 2001; Lalman and Bagley 2000, 2001; Cirne et al., 2007). Most of these results were obtained in batch experiments and indicated a lagphase before methane production induced by LCFA inhibition. During this lag-phase, LCFA degrading bacteria grow and allow the conversion of LCFAs, which encapsulate biomass aggregates, into volatile fatty acids (VFAs), causing degradation of the LCFA capsule around biomass aggregates, after which methanogenesis can take place (Pereira et al., 2005). To avoid destabilisation of the process due to accumulation of LCFAs, the ratio of grease in the influent has to be controlled, and the influence of this ratio on process stability and performance needs to be investigated. In this context, Cirne et al. (2007) showed that inhibition occurred (i.e. presence of a lag-phase) in batch experiments when triolein represented more than $18 \%$ of the total COD of the substrate. However, due to the complex impact of LCFA on anaerobic digestion of the biomass, many experimental factors can have a major impact on results in terms of inhibition. Hwu et al. (1996) reported that their results were influenced by the origin and the structure (suspended or granulated) of the inoculum, while Lalman \& Bagley (2001) reported that their results depended on the composition of the lipid-rich substrate. Results can also be affected by possible acclimation of the biomass, the experimental design (LCFA concentration, temperature, etc) and the concentration of divalent ions in the medium in which the LCFAs can precipitate.

More recently, studies were made of the impact of the lipid to substrate ratio in the influent of an anaerobic CSTR that treated a mixture of primary and secondary sludge. Davidsson et al. (2008) showed that the reactor yield decreased when grease trap sludge (from a municipal WWTP) represented more than $30 \%$ of the volatile solids (VS) of the influent. Luostarinen et al. (2009) observed the same phenomenon with a proportion of grease trap sludge from the food industry of more than $46 \%$ of the VS of the influent. Kabouris et al. (2009) and Silvestre et al. (2011) observed that inhibition did not occur with ratios of lipidrich substrate in the influent of $48 \%$ and $37 \%$ of the feed VS respectively.

According to the results obtained in CSTR and comparing them to those obtained in batch experiments, the frequently cited upper limit of $20 \%$ of greasy waste in the total influent COD does not appear to be accurate and mainly results from batch experiments (Cirne et al., 2007). Few data are available in the literature concerning the possible use of data from batch for_CSTR design. Consequently, in the present study, anaerobic co-digestion of WAS and 
greasy sludge from a flotation process treating waste water from the meat industry was investigated by comparing data from batch and continuous CSTR experiments. First, WAS and greasy sludge were characterised in terms of composition, biodegradability and BMP. Next, batch experiments were performed to investigate the effect of the ratio of greasy sludge to WAS on methane production and inhibition. Finally, the effect of the ratio of greasy sludge to WAS was investigated in a mesophilic CSTR. Reactor yield, VS-COD destruction and stability parameters were determined. These results were compared with those from batch experiments to evaluate the possibility of transposing results from batch experiments to CSTR, in particular concerning inhibition.

\section{Materials and methods}

\subsection{Substrates}

WAS was sampled in a French activated sludge wastewater treatment plant (Mordelles, France) whose capacity is about 10,000 p.e. After settling in the secondary clarifier, WAS was thickened using a thickening table to reach a dry matter content of 5-6\%. For anaerobic digestion experiments (in batch or CSTR), WAS was sampled weekly and stored at $4{ }^{\circ} \mathrm{C}$.

Greasy sludge was sampled in the storage tank of a dissolved air flotation system that processes wastewater from a meat industry (pork processing). Sampling was monthly and samples were stored at $4{ }^{\circ} \mathrm{C}$ until anaerobic digestion tests.

\subsection{Physical-chemical analysis}

Total solids (TS), volatile solids (VS), total Kjeldhal nitrogen (TKN), total ammonia nitrogen (TAN) and total chemical oxygen demand analysis (COD) were measured using standard methods (APHA, AWWA, WEF, 1995). However, before COD analysis, greasy sludge samples were saponified to improve measurement quality: $40 \mathrm{ml}$ of greasy sludge were mixed with $5 \mathrm{ml}$ of $\mathrm{NaOH}(32 \%)$ and $55 \mathrm{ml}$ of distilled water and heated at $60^{\circ} \mathrm{C}$ for $30 \mathrm{~min}$ under mixing. The dilution factor was taken into account in the calculation of COD. Total carbon was determined by elemental analysis (Thermo Flash 2000). Samples were oxidised 
by flash combustion at $1800{ }^{\circ} \mathrm{C}$ and the resulting gas was analysed by gas chromatography combined with catharometric detection.

Total lipid content was determined with a Soxhlet $\odot$ extraction on substrate dry matter. Each substrate was previously dried at $105^{\circ} \mathrm{C}$ and ground to a powder $(1 \mathrm{~mm})$. Soxhlet extraction was carried out with a hexane/isopropanol (60/40) solvent for 5 hours. After evaporation of the solvent, the percentage of hexane extractable materials (HEM) in TS was determined by gravimetry.

For the biochemical fractionations, proteins (as \% COD) were determined from organic $\mathrm{N}$ content considering a ratio of $6.25 \mathrm{~g}$ of protein per $\mathrm{g}$ of organic $\mathrm{N}$ and an average COD value of $1.42 \mathrm{gO} 2 / \mathrm{g}$ of protein (Erreur ! Source du renvoi introuvable.) while lipids were determined from the HEM considering an average COD value of $2.86 \mathrm{gO} / \mathrm{g}$ of lipids (Equation 1). The remaining COD was considered as carbohydrates (Equation 2).

Pr oteins $(\% C O D)=100 \times\left\lfloor 6.25 g_{\text {protein }} / g_{\text {organicN }} \times(T K N-T A N) \times 1.42 g O_{2} / g_{\text {protein }}\right\rfloor / C O D$

Equation 1 : Equation for the calculation of the protein fraction of COD:

$$
\operatorname{Lipids}(\% C O D)=100 \times\left(2.86 g O_{2} / g_{\text {lipid }} \times H E M\right) / C O D
$$

\section{Equation 2 : Equation for the calculation of the lipid fraction of COD:}

$$
\text { Carbohydrates }(\% C O D)=100-\operatorname{Pr} \text { oteins }(\% C O D)-\operatorname{Lipids}(\% C O D)
$$

\section{Equation 3 : Equation for the calculation of the carbohydrate fraction of COD:}

In addition, volatile fatty acids (VFAs) and long chain fatty acids (LCFAs) were analysed by high performance liquid chromatography (HPLC, Varian@, U3000) combined with evaporative light-scattering detection. For VFAs, raw samples were first centrifuged and the supernatant was used for analysis. For LCFA analysis, Soxhlet $\odot$ extraction using the same methodology as described for total lipid extraction was carried out. But to preserve LCFA concentration and characteristics, extraction was performed on the raw sample without previous drying. After extraction, the solvent containing LCFAs was injected into the HPLC. 


\subsection{Batch experiments}

Batch experiments were performed to determine the biochemical methane potential (BMP) of individual substrates and the methane production rate of mixtures of greasy sludge and WAS to check at what ratios inhibition occurs. For this purpose, individual substrate or a mixture of two substrates, inoculum and nutritive solution (Hach@, BOD Nutrient Buffer Pillows) were placed in a 330-ml serum flask. The quantity of substrate was adjusted to maintain a substrate:inoculum ratio of about $1 \mathrm{gVS}_{\text {substrate }} / \mathrm{gVS}_{\text {inoculum. }}$ After filling, the bottles were closed with a rubber cap and the atmospheric oxygen in the gas phase was purged with $\mathrm{N}_{2}$. A batch experiment without substrate was also carried out to determine the endogenous biogas and methane production rate of the inoculum. All batches were performed in triplicate. All bottles containing serum were incubated at $38{ }^{\circ} \mathrm{C}$. Biogas production was monitored daily by pressure measurements (Digitron $(2085 \mathrm{P}$ ). When the pressure in the bottles reached 1300 mbar, a sample of gas was removed and the pressure released. $\mathrm{CH}_{4} / \mathrm{CO}_{2}$ contents of gas samples were analysed by gas chromatography (Agilent Technologies $6890 \mathrm{~N}$ equipped with a flame ionization detector). Biogas and methane production were monitored until the biogas production rate of batch experiments with substrate reached endogenous levels. Finally, the production of biogas or methane in a control without substrate was subtracted from the production of the batch with substrate to obtain the real production rate and the potential of the substrate.

Depending on the experiments, three different inoculums were used. The first inoculum (inoculum 1) was sampled in a mesophilic anaerobic CSTR fed with a mixture of pig slurry and horse feed and operating with an HRT of 27 days and an OLR of $3.9 \mathrm{kgO}_{2} \cdot \mathrm{m}^{-}$ ${ }^{3}$ reactor. $\mathrm{d}^{-1}$. The second inoculum (inoculum 2) was sampled in a CSTR only fed with WAS (HRT: 24 days, OLR $=3 \cdot 6 \mathrm{kgO}_{2} \cdot \mathrm{m}^{-3}$ reactor $\cdot \mathrm{d}^{-1}$ ). The third inoculum (inoculum 3) was sampled in a CSTR fed with a mixture of WAS and greasy sludge (17\% of the feed COD) operating with an HRT of 24 days and an OLR of $3.8 \mathrm{kgO}_{2} \cdot \mathrm{m}^{-3}$ reactor $\cdot \mathrm{d}^{-1}$. Inoculum 1 was used for all batch experiments including BMP determination and mixture studies while specific experiments were carried out for mixtures using inoculums 2 and 3 to investigate the effect of inoculum origin on inhibition results. 


\subsection{CSTR experiments}

CSTR experiments were performed using two different digesters. The first digester (A) was a CSTR with a working volume of $200 \mathrm{~L}$. The temperature was set at $36{ }^{\circ} \mathrm{C}$ and the reactor was fed twice a day by means of a temporized screw pump allowing the volume added to be controlled. An overflow was used for withdrawal to ensure a fixed working volume. A mechanical stirrer was used for mixing. Biogas production was monitored with a volumetric gas counter and the biogas composition was analysed with an infrared analyser (GA 2000 SN, Geotechnical Instruments( $)$.

The second digester (B) was a CSTR with working volume of $3.4 \mathrm{~L}$. Mixing was performed by recirculating the sludge from the bottom of the reactor to the top. A peristaltic pump ensured a fixed input volume. Biogas production was monitored with a volumetric gas counter and biogas was analysed by gas chromatography as described in section 2.3. Other configuration parameters were the same those used in reactor A.

All CSTR experiments were divided into nine successive runs in which increasing greasy sludge ratios in the influent $\left(\frac{\text { greasy sludge }}{\text { greasy sludge }+ \text { WAS }}\right.$, expressed as a $\%$ of the total feed COD) from $0 \%$ to $90 \%$ were evaluated. The first three runs were performed in reactor A (run $1 \mathrm{~A}, 2 \mathrm{~A}$ and $3 \mathrm{~A}$ ) and the six other runs were performed using digester $\mathrm{B}$ (run 4B, 5B, 6B, 7B, $8 \mathrm{~B}$ and $9 \mathrm{~B})$. Between each run, a transition week was inserted with a greasy sludge ratio equal to the mean of the former and the following ratio. To check if the results using the two digesters could be compared, a similar run was carried out using the same ratio of greasy sludge to WAS in the digesters feed (run $3 \mathrm{~A}$ and run 4B).

In all cases, feedings were defined to obtain an HRT of about 25 days and an organic loading rate (OLR) of $3 \mathrm{kgCOD} \cdot \mathrm{m}^{-3}$ reactor $\cdot \mathrm{day}^{-1}$. The influent mixture was designed to maintain these parameters and the greasy sludge to WAS ratio by means of COD analyses. For high greasy sludge ratios, the mixture was diluted with tap water to maintain a fixed total concentration of COD in the influent.

For each greasy sludge ratio, CSTR efficiencies were calculated after a one month period of stabilisation of the digester outputs (biogas production and effluent contents). Thus, digester performances were calculated for a 3-week steady state period. The total duration of CSTR experiments including all the runs was 21 months. 


\section{Results and discussion}

\subsection{Substrate characteristics}

Physical-chemical properties of WAS and greasy sludge are listed in Table 1.

\begin{tabular}{|c|c|c|c|c|c|}
\hline \multirow[b]{2}{*}{ Parameters } & \multirow[b]{2}{*}{ Units } & \multicolumn{2}{|c|}{ WAS } & \multicolumn{2}{|c|}{ Greasy sludge } \\
\hline & & Mean value & $\begin{array}{l}\text { Relative } \\
\text { standard } \\
\text { deviation }\end{array}$ & Mean value & $\begin{array}{l}\text { Relative } \\
\text { standard } \\
\text { deviation }\end{array}$ \\
\hline$\overline{\mathrm{pH}}$ & - & 6.5 & $1.4 \%$ & 5.5 & $2.8 \%$ \\
\hline TS & ${\mathrm{g} . \mathrm{kg}^{-1}}^{-1}$ & 57.0 & $6.5 \%$ & 95.8 & $20.1 \%$ \\
\hline \multirow{2}{*}{ VS } & g.kg ${ }^{-1}$ & 45.8 & $9.2 \%$ & 86.3 & $21.6 \%$ \\
\hline & $\% \mathrm{TS}$ & 80.2 & $4.3 \%$ & 89.8 & $2.8 \%$ \\
\hline \multirow{2}{*}{ Total COD } & $\mathrm{gO}_{2} \cdot \mathrm{kg}^{-1}$ & 75.2 & $5.9 \%$ & 195.7 & $20.8 \%$ \\
\hline & $\mathrm{gO}_{2} \cdot \mathrm{gVS}^{-1}$ & 1.6 & $5.9 \%$ & 2.2 & $10.1 \%$ \\
\hline$\overline{\text { TKN }}$ & gN.kg ${ }^{-1}$ & 4.6 & $12.0 \%$ & 1.9 & $10.0 \%$ \\
\hline TAN & gN.kg ${ }^{-1}$ & 0.1 & $75.8 \%$ & 0.1 & $74.1 \%$ \\
\hline Total C & $\mathrm{gC}^{\mathrm{kg}} \mathrm{g}^{-1}$ & 26.8 & $14.8 \%$ & 78.2 & $19.4 \%$ \\
\hline $\mathbf{C} / \mathbf{N}$ & $\mathrm{gC}_{\mathrm{g}} \mathrm{gN}^{-1}$ & 5.8 & - & 41.6 & - \\
\hline \multirow{2}{*}{ Protein } & $\% \mathrm{VS}$ & 60.6 & - & 11.4 & - \\
\hline & $\% \mathrm{COD}$ & 51.3 & - & 7.5 & - \\
\hline \multirow{2}{*}{ Lipid } & $\% \mathrm{VS}$ & 9.7 & - & 50.1 & - \\
\hline & $\% \mathrm{COD}$ & 17.2 & - & 64.1 & - \\
\hline \multirow{2}{*}{ Carbohydrates } & $\% \mathrm{VS}$ & 29.6 & - & 37.5 & - \\
\hline & $\% \mathrm{COD}$ & 31.5 & - & 28.4 & - \\
\hline Total P & gp.kg $^{-1}$ & 2.6 & - & 0.15 & - \\
\hline $\mathrm{Ca}^{2+}$ & $\mathrm{mg}_{\mathrm{Ca} 2+\mathrm{kgTS}^{-1}}$ & 889.2 & - & 3171.0 & - \\
\hline $\mathrm{Mg}^{2+}$ & $\mathrm{mgMg}^{+} \cdot \mathrm{kgTS}^{-1}$ & 399.0 & - & 98.6 & - \\
\hline \multirow{3}{*}{$\mathbf{B M P}$ methane } & NL.kg ${ }^{-1}$ & 11.7 & $22.8 \%$ & 74.1 & $19.1 \%$ \\
\hline & NL.kgVS $^{-1}$ & 255.4 & $17.4 \%$ & 871.6 & $14.7 \%$ \\
\hline & NL.kgCOD ${ }^{-1}$ & 155.2 & $17.0 \%$ & 379.9 & $3.1 \%$ \\
\hline \multirow{2}{*}{$\mathbf{B M P}_{\text {biogaz }}$} & NL.kg-1 & 18.6 & $23.9 \%$ & 92.6 & $12.7 \%$ \\
\hline & NL.kgVS $^{-1}$ & 405.7 & $19.0 \%$ & 1096.6 & $14.1 \%$ \\
\hline Methane/biogas & $\%$ & 63.2 & $3.1 \%$ & 79.6 & $9.2 \%$ \\
\hline Biodegradability & $\% \mathrm{COD}$ & 44.3 & - & 108.5 & - \\
\hline
\end{tabular}

Table 1 : Complete characterization of WAS and greasy sludge.

Significant differences between the two substrates were observed. TS content was respectively $57.0 \mathrm{~g} . \mathrm{kg}^{-1}$ and $95.8 \mathrm{~g} . \mathrm{kg}^{-1}$ for WAS and greasy sludge. Major differences were also observed in the biochemical fractionation of the organic matter in each substrate. As 
expected, the majority of VS in greasy sludge is formed by lipids $(50.1 \%$ of the VS and $64.1 \%$ of the total COD), whereas proteins formed the majority of the VS in WAS $(60.6 \%$ of the VS and $51.3 \%$ of the total COD). Despite the origin of the greasy sludge, the carbohydrate fraction of the VS was significant (37.5\% of the VS and $28.4 \%$ of the total COD). These properties resulted in very different $\mathrm{C} / \mathrm{N}$ values: $5.8 \mathrm{gC} \cdot \mathrm{gN}^{-1}$ and $41.6 \mathrm{gC} \cdot \mathrm{gN}^{-1}$ for WAS and greasy sludge respectively. WAS presented a BMP value of $11.7 \mathrm{NL}_{\mathrm{ch} 4} \cdot \mathrm{kg}^{-1}$ $\left(155.2 \mathrm{NL}_{\mathrm{ch} 4} \cdot \mathrm{kgVS}^{-1}\right)$ with a methane concentration of $63.2 \%$ in the biogas. Greasy sludge presented a BMP value of $74.1 \mathrm{NL}_{\mathrm{ch} 4} \cdot \mathrm{kg}^{-1}\left(871.6 \mathrm{NL}_{\mathrm{ch} 4} \cdot \mathrm{kgVS}^{-1}\right)$ and a methane content of $79.6 \%$ in the biogas. This BMP value is in accordance with values cited in the literature for

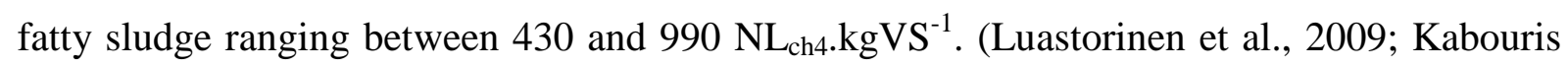
et al., 2009; Silvestre et al., 2010). In addition to VS biochemical fractionation, differences in biodegradability values explain the observed BMP values. In fact, the biodegradability of greasy sludge COD is very high (slightly higher than $100 \%$ due to analysis incertitude) in comparison with values obtained for WAS (44\% on the basis of COD). Given the possible

precipitation of LCFA with $\mathrm{Mg}^{2+}$ and $\mathrm{Ca}^{2+}$ and considering theoretical stoichiometric ratios, this phenomenon concerned a maximum of 5\% of the total substrate COD for WAS and 7\% for greasy sludge. Hence, this phenomenon cannot have a significant impact on the accessibility and biodegradability of either substrate.

In conclusion, because of its high BMP value, greasy sludge resulting from a flotation process is a potentially usable co-substrate for co-digestion with WAS. In addition, due to its low $\mathrm{N}$ and $\mathrm{P}$ contents and its high biodegradability, using it as a co-substrate would have only a slight impact on the N and P loading rates of the WWTP (back to top of the liquid fraction after dewatering) and the sludge production respectively.

\subsection{Batch experiments}

Batch experiments were carried out to investigate the maximum ratio of lipid-rich effluent to incorporate in WAS. The effect of the origin of the inoculum on batch results in terms of BMP of the mixture and inhibitions was also investigated by comparing the results of inoculum 1, 2 and 3.

Batch experiments were carried with four different greasy sludge to WAS ratios, in which greasy sludge represented 10, 20, 30 and $40 \%$ of the total COD of the substrates. For 
each ratio (except 40\%), the three previously described inoculums were used and the resulting $\mathrm{BMP}$ of the mixtures is presented in Figure 1.

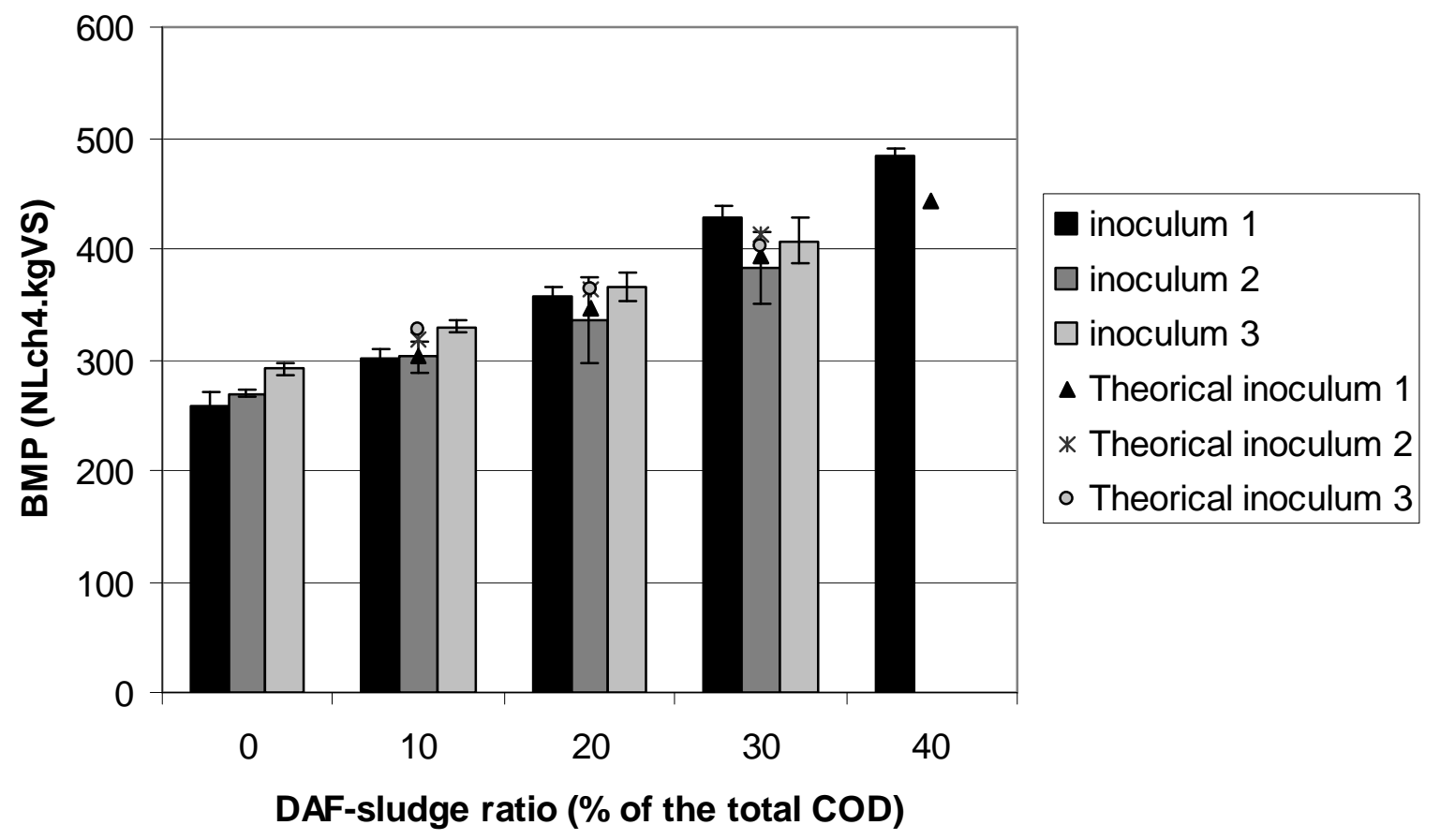

Figure 1: Biochemical methanogenic potential of the mixtures of WAS with greasy sludge as a function of the greasy sludge to WAS ratio

Theoretical BMP values were calculated considering the proportional sum of BMP value obtained on the individual substrates.

There was no significant difference in the results obtained with any of the different ratios whatever the inoculum used, showing that the origin of the inoculum had no significant effect on the BMP of the mixture. Moreover, the BMP of the mixtures were close to the theoretical BMP calculated based on the proportional sum of the BMP values obtained with individual substrates. This means that neither synergism nor antagonism (due to inhibition) affected BMP results after 40 days of incubation. The BMP values obtained were respectively $273,310,353,406$ and $483 \mathrm{NL}_{\mathrm{ch} 4} \cdot \mathrm{kgVS}^{-1}$.for ratios of $0,10,20,30$ and $40 \%$ of greasy sludge in the total COD of the substrate mixture. The addition of greasy sludge to WAS affected the proportion of methane in the biogas. Without greasy sludge, the resulting biogas contained $63 \%$ of methane while, in comparison, for a greasy sludge ratio of $10,20,30$ and $40 \%$ in COD basis, the biogas contained respectively $65,67,68$ and $68 \%$ of methane. These results are combined with an increase in the biodegradability of the COD and the VS of the mixtures. Based on COD, mean biodegradability was 49, 54, 60, 67 and 78\% (39, 43, 47, 53 and 62\% 
based on VS) for ratios of $0,10,20,30$ and $40 \%$ of greasy sludge in the total COD. As expected, the addition of greasy sludge increased the total biodegradability of the mixture due to the high biodegradability of this substrate (close to $100 \%$, as highlighted in table 1).

Batch results also provide information on biodegradation kinetics and were thus used to investigate inhibition. Figure 2 presents the cumulative production of methane in batch experiments with inoculum 1 at the different greasy sludge ratios tested. Results are presented as a percentage of BMP reached as a function of time.

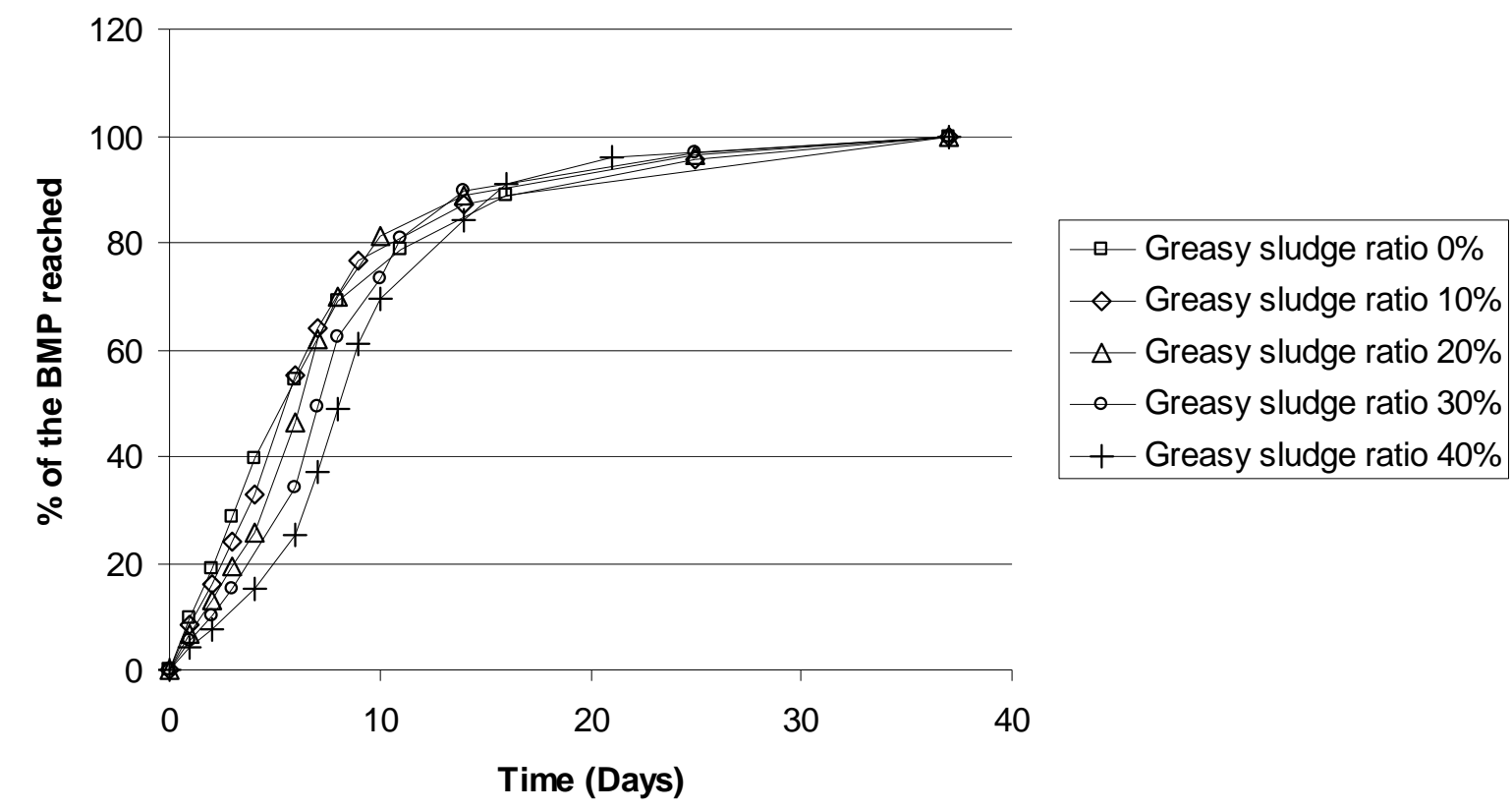

Figure 2: Methane production from batch experiments with inoculum 1 for the different greasy sludge ratio tested (expressed in \% of the final BMP).

With a greasy sludge ratio of $20 \%$ of the total COD in the mixture, the methane production rate decreased significantly at the beginning of the curve. This signaled the beginning of an inhibitory effect due to the addition of greasy sludge. Nevertheless, no real lag-phase occurred, just a decrease in methane production kinetics. Hence, inhibition can be considered as not very strong. The impact of the origin of the inoculum on batch results in terms of inhibition was also investigated. To this end, the results obtained with the three inoculums were compared for inhibition. Figure 3 shows the $\%$ of the BMP reached at 5, 10 and 20 days for the different greasy sludge ratios tested, for each inoculum. 


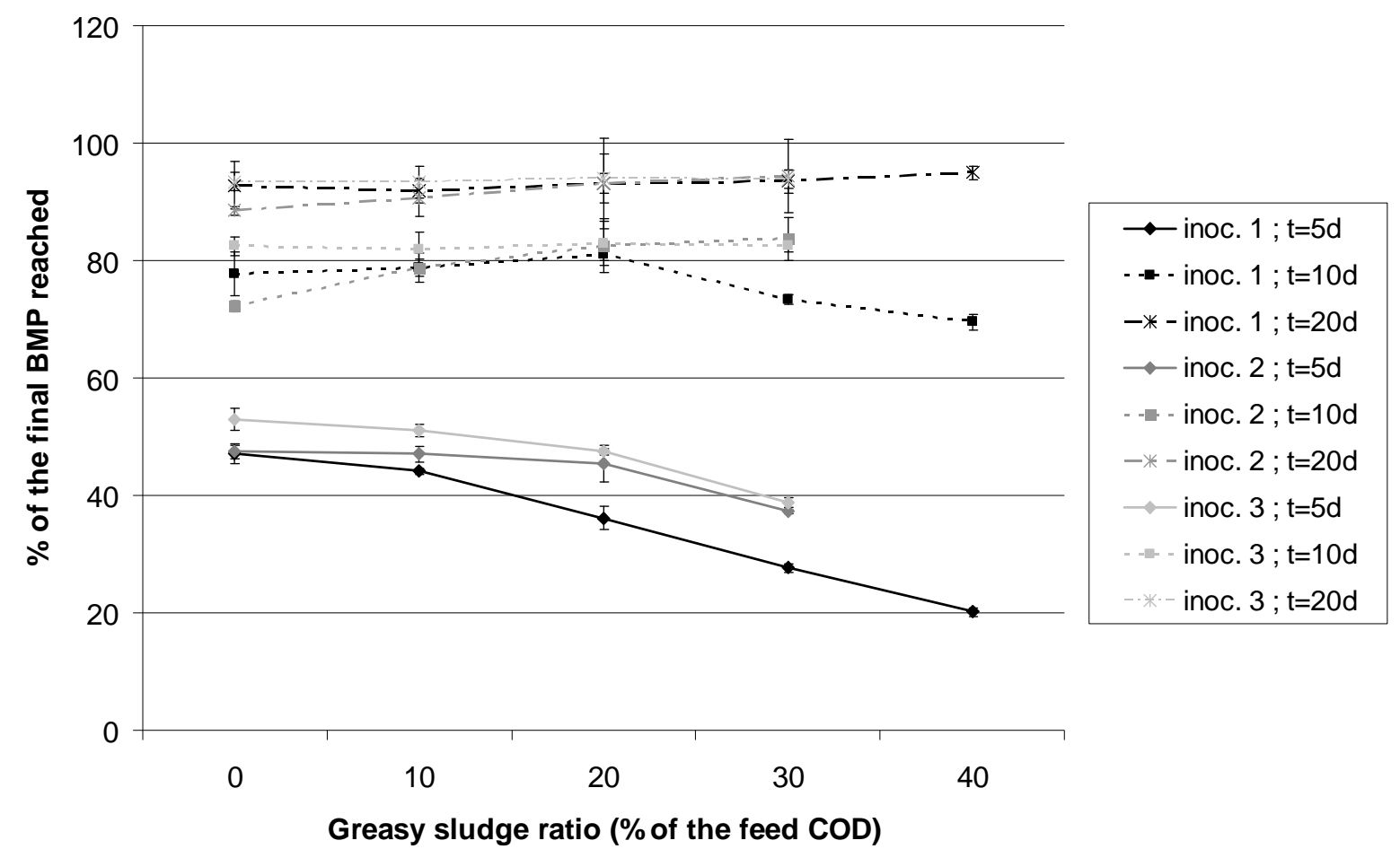

Figure 3: Effect of the greasy sludge ratios in batch experiments on the mean methane production rate at time 5,10 and 20 days.

Observed inhibition was highest with inoculum 1 (from a digestor processing pure WAS). Indeed, a significant decrease in initial methane production rate was observed at a greasy sludge ratio of $20 \%$. In contrast, with inoculum 2 (from a digestor processing WAS+greasy sludge), no reduction in the methane production rate was observed during the 5 first days up to a greasy sludge ratio of $30 \%$. The batch experiments performed with inoculum 3 (from a digester processing pig slurry) showed slight inhibition from a greasy sludge ratio of $30 \%$. Except for with inoculum 1, inhibiting effects had disappeared after 10 days of incubation. After 20 days of incubation, all inhibitory effects had disappeared.

To sum up, inhibition occurred for a greasy sludge ratio between 20 and $30 \%$ of the total substrate COD, depending on the inoculum. However, the origin of the inoculum appeared to have a significant effect on the results of batch experiments in terms of inhibition mainly due to acclimation of the inoculum and consequently the use of such results for designing continuous CSTR processes would probably not be simple. 


\subsection{CSTR experiments}

\subsubsection{Biogas production}

The maximum ratio of lipid rich effluent to incorporate with WAS was also investigated in a CSTR configuration. For this purpose, nine different greasy sludge ratios (from $0 \%$ to $90 \%$ ) were evaluated based on total COD. CSTR experiments were carried out with an increasing ratio of greasy sludge to allow biomass acclimation in the reactor. To avoid effects of other configuration parameters than the greasy sludge ratio in the influent, OLR and the HRT were maintained as constant as possible during the experimental runs. However, due to variations in substrate contents and in operational conditions, some variations were observed. HRT ranged between 24 and 30 days with a mean value of 25 days. OLR ranged between 2.5 and $3.8 \mathrm{kgCOD} . \mathrm{m}^{-3}$ reactor. day $^{-1}$ with a mean value of $3.1 \mathrm{kgCOD} \cdot \mathrm{m}^{-3}$ reactor. $\mathrm{day}^{-1}$. The substrate mixture was designed to maintain these two parameters as constant as possible. As a result, due to the different ratios of COD to VS for each substrate (1.6 and 2.3 for WAS and greasy sludge respectively), the OLR based on VS decreased with an increase in the greasy sludge ratio in the mixture. This parameter decreased from 1.9 to $1.0 \mathrm{kgVS} . \mathrm{m}^{-}$ ${ }^{3}$ reactor.day ${ }^{-1}$ for a greasy sludge ratio of 0 and $90 \%$ respectively. Biogas and methane production were monitored.

First, COD mass balance was calculated for each run considering the input COD stream in the digester and the output COD stream in the digester ( $\mathrm{CH} 4$ and effluent) from Equation 4 in order to check the reliability of each experiment. For the COD of $\mathrm{CH}_{4}$, a

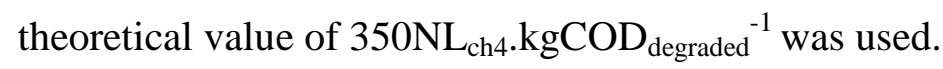

$$
\text { COD mass balance }(\%)=\mathrm{COD}_{\mathrm{CH} 4}+\mathrm{COD}_{\text {effluent }} / \mathrm{COD}_{\text {influent }}
$$

\section{Equation 4 : Calculation of total mass balance of the COD.}

Except for the period corresponding to a greasy sludge ratio of $90 \%$, the COD mass balance obtained ranged from $89 \%$ to $122 \%$. Thus, a maximum difference of $22 \%$ was observed with the theoretical value of $350 \mathrm{NL}_{\mathrm{ch} 4} \cdot \mathrm{kgCOD}_{\text {degraded }}{ }^{-1}$. Considering measurement uncertainty, these results confirm that the experimental reactor was equilibrated when the calculations were made for each ratio. For a greasy sludge ratio of $90 \%$, the mass balance of the COD was significantly less than $100 \%$ (54\%). This difference can be explained by instabilities due to inhibition or problems involved in measuring COD. 
Experimental results in terms of reactor yield and biogas production are presented in Table 2

\begin{tabular}{|c|c|c|c|c|c|c|c|c|c|c|}
\hline \multicolumn{2}{|c|}{$\begin{array}{r}\text { Run } \\
\end{array}$} & $1 \mathbf{A}$ & $2 \mathrm{~A}$ & 3A & 4B & 5B & $6 B$ & 7B & 8B & 9B \\
\hline \multicolumn{11}{|c|}{ Configuration parameters } \\
\hline \multirow{2}{*}{$\begin{array}{c}\text { Greasy } \\
\text { sludge ratio }\end{array}$} & $\%_{\mathrm{COD}}$ & $0 \%$ & $10 \%$ & $17 \%$ & $19 \%$ & $28 \%$ & $42 \%$ & $60 \%$ & $80 \%$ & $90 \%$ \\
\hline & $\%$ vs & $0 \%$ & $7 \%$ & $13 \%$ & $15 \%$ & $22 \%$ & $34 \%$ & $52 \%$ & $74 \%$ & $87 \%$ \\
\hline HRT & days & 24 & 30 & 24 & 25 & 26 & 25 & 24 & 24 & 25 \\
\hline \multirow{2}{*}{ OLR } & $\mathrm{kgO}_{2} \cdot \mathrm{m}_{\text {reactor }} \cdot \mathrm{d}^{-1}$ & 3.6 & 2.9 & 3.8 & 3.2 & 2.9 & 3.0 & 3.0 & 2.7 & 2.5 \\
\hline & $\mathrm{kgVS} \cdot \mathrm{m}^{-3}$ reactor $\mathrm{d}^{-1}$ & 1.9 & 1.8 & 2.0 & 1.7 & 1.6 & 1.4 & 1.2 & 1.0 & 0.8 \\
\hline \multicolumn{11}{|c|}{ Biogas production } \\
\hline $\begin{array}{l}\text { COD mass } \\
\text { balance }\end{array}$ & $\%$ & 107 & 97 & 118 & 122 & 89 & 102 & 105 & 95 & 54 \\
\hline \multirow{4}{*}{$\begin{array}{l}\text { Methane } \\
\text { produced }\end{array}$} & $\mathrm{NL}_{\mathrm{ch} 4} \cdot \mathrm{kg}_{\text {CODintroduced }}{ }^{-1}$ & 136 & 138 & 174 & 172 & 162 & 185 & 215 & 171 & 53 \\
\hline & $\mathrm{NL}_{\mathrm{ch} 4} \cdot \mathrm{kg}_{\text {VSintroduced }}{ }^{-1}$ & 264 & 180 & 333 & 324 & 292 & 398 & 546 & 454 & 158 \\
\hline & $\mathrm{NL}_{\mathrm{ch} 4} \cdot \mathrm{m}_{\text {reactor }}^{-3} \cdot \mathrm{d}^{-1}$ & 490 & 399 & 658 & $549 \pm 43$ & $464 \pm 23$ & $576 \pm 18$ & $669 \pm 41$ & $468 \pm 35$ & $135 \pm 16$ \\
\hline & $\begin{array}{l}\mathrm{NL}_{\mathrm{ch} 4} \cdot \mathrm{m}^{-3} \text { reactor. } \mathrm{d}^{-1} \\
\left(\mathrm{OLR}=3 \mathrm{kgO}_{2} \cdot \mathrm{m}^{-}\right. \\
\left.{ }_{\text {reactor }} \cdot \mathrm{d}^{-1}\right)^{*}\end{array}$ & 408 & 413 & 520 & $516 \pm 40$ & $482 \pm 24$ & $576 \pm 18$ & $662 \pm 41$ & $518 \pm 39$ & $164 \pm 19$ \\
\hline \multirow{4}{*}{$\begin{array}{l}\text { Biogas } \\
\text { produced }\end{array}$} & $\mathrm{NL}_{\text {biogas }} \cdot \mathrm{kg}_{1} \mathrm{CODintroduced}^{-}$ & 207 & 166 & 252 & 258 & 242 & 275 & 312 & 252 & 85 \\
\hline & $\mathrm{NL}_{\text {biogas }} \cdot \mathrm{kg}_{\mathrm{V}_{\text {Sintroduced }}}{ }^{-1}$ & 400 & 274 & 480 & 486 & 437 & 591 & 793 & 669 & 262 \\
\hline & $\mathrm{NL}_{\text {biogas }} \cdot \mathrm{m}_{\text {reactor }}^{-3} \mathrm{~d}^{-1}$ & 744 & 607 & 945 & $823 \pm 63$ & $694 \pm 35$ & $857 \pm 36$ & $972 \pm 56$ & $690 \pm 48$ & $214 \pm 24$ \\
\hline & $\begin{array}{l}\mathrm{NL}_{\text {biogas }} \cdot \mathrm{m}^{-3} \text { reactor } \cdot \mathrm{d}^{-1} \\
\quad(\mathrm{OLR}= \\
\left.3 \mathrm{kgO}_{2} \cdot \mathrm{m}_{\text {reactor }}^{-3} \cdot \mathrm{d}^{-1}\right)^{*}\end{array}$ & 620 & 628 & 746 & $773 \pm 59$ & $721 \pm 36$ & $858 \pm 36$ & $964 \pm 56$ & $764 \pm 53$ & $261 \pm 29$ \\
\hline $\mathrm{CH}_{4}$ content & $\%$ & $66 \pm 2$ & $66 \pm 21$ & $69 \pm 2$ & $67 \pm 1$ & $67 \pm 1$ & $67 \pm 2$ & $69 \pm 1$ & $69 \pm 1$ & $63 \pm 1$ \\
\hline \multicolumn{11}{|c|}{ Material destruction } \\
\hline $\begin{array}{c}\text { VS } \\
\text { destruction }\end{array}$ & $\%$ & 29 & 43 & 36 & 42 & 42 & 39 & 44 & 33 & 17 \\
\hline $\begin{array}{c}\text { COD } \\
\text { destruction } \\
\end{array}$ & $\%$ & 36 & 39 & 42 & 40 & 52 & 52 & 59 & 51 & 28 \\
\hline $\begin{array}{c}\text { Protein } \\
\text { destruction }\end{array}$ & $\%$ & 40 & - & - & 43 & 37 & 28 & 30 & 13 & 16 \\
\hline \multicolumn{11}{|c|}{ Stability parameters } \\
\hline $\mathrm{pH}$ & & 7.3 & 7.3 & 7.3 & 7.4 & 7.3 & 7.2 & 7.2 & 7.2 & 6.9 \\
\hline \multirow{5}{*}{ LCFAs } & $\mathrm{mg}_{\text {ac.-oleic }} \cdot \mathrm{kg}^{-1}$ & $<30$ & - & - & 31 & 147 & nd. & 182 & 579 & 253 \\
\hline & $\mathrm{mg}_{\text {ac.-stearic }} \cdot \mathrm{kg}^{-1}$ & $<30$ & - & - & 75 & 244 & 246 & 590 & 1739 & 1562 \\
\hline & $\mathrm{mg}_{\text {ac.-linoleic }} \cdot \mathrm{kg}^{-1}$ & $<30$ & - & - & $<30$ & $<30$ & $<30$ & $<30$ & $<30$ & $<30$ \\
\hline & $\mathrm{mg}_{\text {ac.-palmitic }} \cdot \mathrm{kg}^{-1}$ & $<30$ & - & - & 247 & 506 & 552 & 2150 & 4733 & 4152 \\
\hline & $\mathrm{mg}_{\text {ac.-palmitoleic }} \cdot \mathrm{kg}^{-1}$ & $<30$ & - & - & $<30$ & $<30$ & $<30$ & $<30$ & $<30$ & 33 \\
\hline VFAs & $\mathrm{mg}_{\text {acetate }} \cdot \mathrm{kg}^{-1}$ & $<50$ & $<50$ & $<50$ & $<50$ & $<50$ & $<50$ & 69 & 589 & 331 \\
\hline $\begin{array}{l}\text { Maximum } \\
\text { VFA } \\
\text { accumulation } \\
\text { during the } \\
\text { loading } \\
\text { phase }\end{array}$ & $\mathrm{mg}_{\text {acetate }} \cdot \mathrm{kg}^{-1}$ & $<50$ & - & - & $<50$ & 105 & $<50$ & 1201 & 599 & 640 \\
\hline $\begin{array}{l}\mathrm{C} / \mathrm{N} \text { of the } \\
\text { influent }\end{array}$ & $\mathrm{gC} \cdot \mathrm{gN}^{-1}$ & 6.0 & - & - & 7.2 & 7.8 & 9.4 & 13.6 & 20.1 & 26.8 \\
\hline $\begin{array}{l}\text { TAN in the } \\
\text { effluent }\end{array}$ & $\mathrm{gN} \cdot \mathrm{kg}^{-1}$ & 1.4 & - & - & 1.4 & 1.1 & 0.9 & 0.8 & 0.7 & 0.5 \\
\hline
\end{tabular}

Table 2: Process parameters and results obtained for co-digestion of WAS with greasy sludge in CSTR.

*: Reactor yield was proportionally corrected to convert experimental yield into a standardized yield considering an OLR of $3 \mathrm{kgO}_{2} \cdot \mathrm{m}^{-3}$ reactor. $\mathrm{d}^{-1}$. 
Even if some variations were observed due to slight variations in substrate properties over time (contents and biodegradability), methane and biogas production increased up to a greasy sludge ratio of $60 \%$. In order to compare the results of all the experiments, a normalised reactor yield for methane production was calculated based on the experimental results and a fixed OLR $\left(3 \mathrm{kgO}_{2} \cdot \mathrm{m}^{-3} \cdot \mathrm{d}^{-1}\right)$. For this calculation, the reactor yield was considered as proportional to the OLR in the range of variation observed in the CSTR reactor. Hence, the normalised reactor yield increased from 408 to $662 \mathrm{NL}_{\mathrm{ch} 4} \cdot \mathrm{m}^{3}$ reactor.day ${ }^{-1}$ with a greasy sludge ratio which increased from $0 \%$ to $60 \%$. The same results were observed for biogas production associated with an increase in the methane content in the biogas from $66 \%$ to $69 \%$ at the same greasy sludge ratios. The increase in methane production and in reactor yield was mainly due to the increase in the overall biodegradability of the substrate mixture, as greasy sludge is more biodegradable than WAS. These results can be linked with the increase in the destruction of COD from $36 \%$ to $59 \%$ with an increase in the greasy sludge ratio from $0 \%$ to $60 \%$. An increase in VS destruction was also observed, but due to variations in the ratio of influent COD to VS, the trend was less clear. When the greasy sludge ratio increased from $60 \%$ to $80 \%$ and $90 \%$ based on COD, the trend was reversed and the normalized reactor yield decreased from 662 to 518 and finally to $164 \mathrm{NL}_{\mathrm{ch} 4} \cdot \mathrm{m}^{3}$ reactor.day ${ }^{-1}$ respectively. These results can be linked with biogas production and COD or VS destruction measurements. In addition, the increase in the greasy sludge ratio influenced the protein destruction rate, which decreased slightly from a greasy sludge ratio of $42 \%$ of the feed COD (from $40 \%$ for a greasy sludge ratio of $0 \%$ to $28 \%$ for a greasy sludge ratio of $42 \%$, see Table 2). A greasy sludge ratio of more than $60 \%$ of the feed COD, strongly reduced the protein degradation rate which can be linked with the decrease in the VS destruction rate. This phenomenon was already observed by Ponsà et al. (2011) during co-digestion of the organic fraction of municipal solid waste with vegetable oil. Concerning the biogas characteristics, even when the methane content was maintained at $69 \%$ with a greasy sludge ratio of $80 \%$, it decreased to $63 \%$ with a greasy sludge ratio of $90 \%$.

These results are in agreement with those obtained by Luostarinen et al. (2009) during co-digestion of sewage sludge (mixture of primary sludge and WAS) and grease trap sludge from a meat processing plant. These authors report an optimal co-digestion reactor yield for a grease-trap sludge ratio of $46 \%$ of the VS. With higher ratios, the reactor yield decreased. In our study, based on VS, the optimal greasy sludge ratio was 52\%. Reduction of VS in Luostarinen et al. (2009) was higher than in our case due to the higher biodegradability of 
primary sludge in comparison to WAS. Davidsson et al. (2008) investigated the feasibility of co-digestion of grease trap sludge with sewage sludge and observed a decrease in CSTR yield above a grease trap sludge ratio in the influent of $30 \%$ based on VS. The discrepancy between these results and the results of the present study can be explained by the difference in the reactor configuration (HRT $=13$ days) and the different characteristics of the sewage sludge (50\% of primary sludge $+50 \%$ of WAS) and of the fatty substrate. It raises the question of the choice of an accurate indicator of the fatty substrate ratio in the influent. Ratios based on VS or COD are commonly used. Nevertheless, in the present study, lipids represented only $50 \%$ of the VS of greasy sludge (see Table 1). Hence, taking into account the lipid content of greasy sludge and WAS, the optimal lipid ratio in the influent would be $31 \%$ based on VS. This highlights the importance of combining experimental evaluations with complete characterization of the substrates used to obtain consistent results.

\subsubsection{Process stability}

In addition to reactor yield, different parameters were monitored during each run to provide information on process stability and on the origin of any inhibition. All these data are presented in Table 2. During all experimental periods, the $\mathrm{pH}$ value remained relatively stable even if a slight decrease (from 7.2 to 6.9) was observed with an increase in the greasy sludge ratio from 80 to $90 \%$ in the feed COD. During the experiments, no accumulation of VFAs was observed when the greasy sludge ratio did not exceed $60 \%$. With greasy sludge ratios of 80 and 90\%, a slight accumulation of acetate was observed (589 and $331 \mathrm{mg}_{\text {acetate. }} \cdot \mathrm{kg}^{-1}$, respectively). These accumulations revealed the instability of the process and an inhibition of acetotrophic methanogenesis. However, the accumulations were not very high and did not seriously affect $\mathrm{pH}$ as the substrates were buffered by ammonia and carbonate concentrations. Working on a mixture of primary sludge, WAS and grease-trap sludge, Luostarinen et al. (2009) observed total VFA accumulation of not more than $430 \mathrm{mg}^{-\mathrm{L}^{-1}}$ with a high ratio of grease trap sludge in the influent mixture (71\% of the feed VS).

On the contrary, monitoring of LCFA concentrations in the effluent revealed significant accumulations. The main LCFAs that accumulated were palmitic, stearic and oleic acids. The concentration of palmitic acid increased from $247 \mathrm{mg} . \mathrm{L}^{-1}$ to 4733 with an increase in greasy sludge ratio from 19 to $80 \%$ of the feed COD. The same phenomenon was observed for stearic acid whose concentration in the effluent was $75 \mathrm{mg} . \mathrm{L}^{-1}$ for a greasy sludge ratio of 
$19 \%$ and reached $1739 \mathrm{mg} . \mathrm{L}^{-1}$ for a greasy sludge ratio of $80 \%$. Oleic acid accumulation was lower and reached a maximum value of $426 \mathrm{mg}^{-\mathrm{L}^{-1}}$ for a greasy sludge ratio of $80 \%$. Palmitic acid has already been identified as the main accumulated LCFA in batch experiments using fatty poultry slaughterhouse wastes (Salminen et al., 2000). On the other hand, Lalman and Bagley $(2000,2001)$ reported that palmitic acid accumulated during the degradation of oleic and linoleic acids. Beccari et al. (1998) observed that the conversion of stearic acid (C18:0) into palmitic acid (C16:0) is very rapid. As VFA accumulation was not particularly high, methanogenesis cannot be considered as the only stage to be impacted and at least acidogenesis and acetogenesis were impacted too. So, by inducing an excess of lipids, too much greasy sludge in the reactor feed leads to an overall decrease in degradation kinetics. The observed accumulation of LCFAs at greasy sludge ratios of 80 and $90 \%$ was significantly higher than IC50 values in the literature, i.e., between 30 and $1350 \mathrm{mg}_{\mathrm{LCFA}} \cdot \mathrm{kg}^{-1}$ depending on the LCFA concerned, as well as on the origin of the biomass and its physical structure (Koster and Kramer, 1987; Hwu et al., 1996; Alves et al., 2001). Our results are in agreement with those in the literature where methanogenesis is not the only stage affected (Alves et al., 2001; Lalman and Bagley 2002; Cirne et al., 2007). This phenomenon cannot be explained by a lack of mineral nitrogen for biomass growth because the $\mathrm{C} / \mathrm{N}$ ratio inferior to 30 , as recommended by Parkin and Owen (1986). Moreover, for greasy sludge ratios of more than $60 \%$ of the feed $\mathrm{COD}$, the presence of fatty materials is visible in the reactor effluent and biomass aggregates tend to float. As a result, the inhibition effects observed in this study are probably due to mass transfer limitation due to LCFA accumulation on and in the biomass aggregates as highlighted by Pereira et al. (2005). The resulting encapsulation limited the exchange between the reactor media (including substrate) and biomass, hence reducing the degradation kinetics.

\subsection{CSTR versus batch experiments}

A comparison of the effect of the greasy sludge ratio on the reactor yield obtained from CSTR experiments and calculated from batch experiments without considering inhibition is presented in Figure 4. 


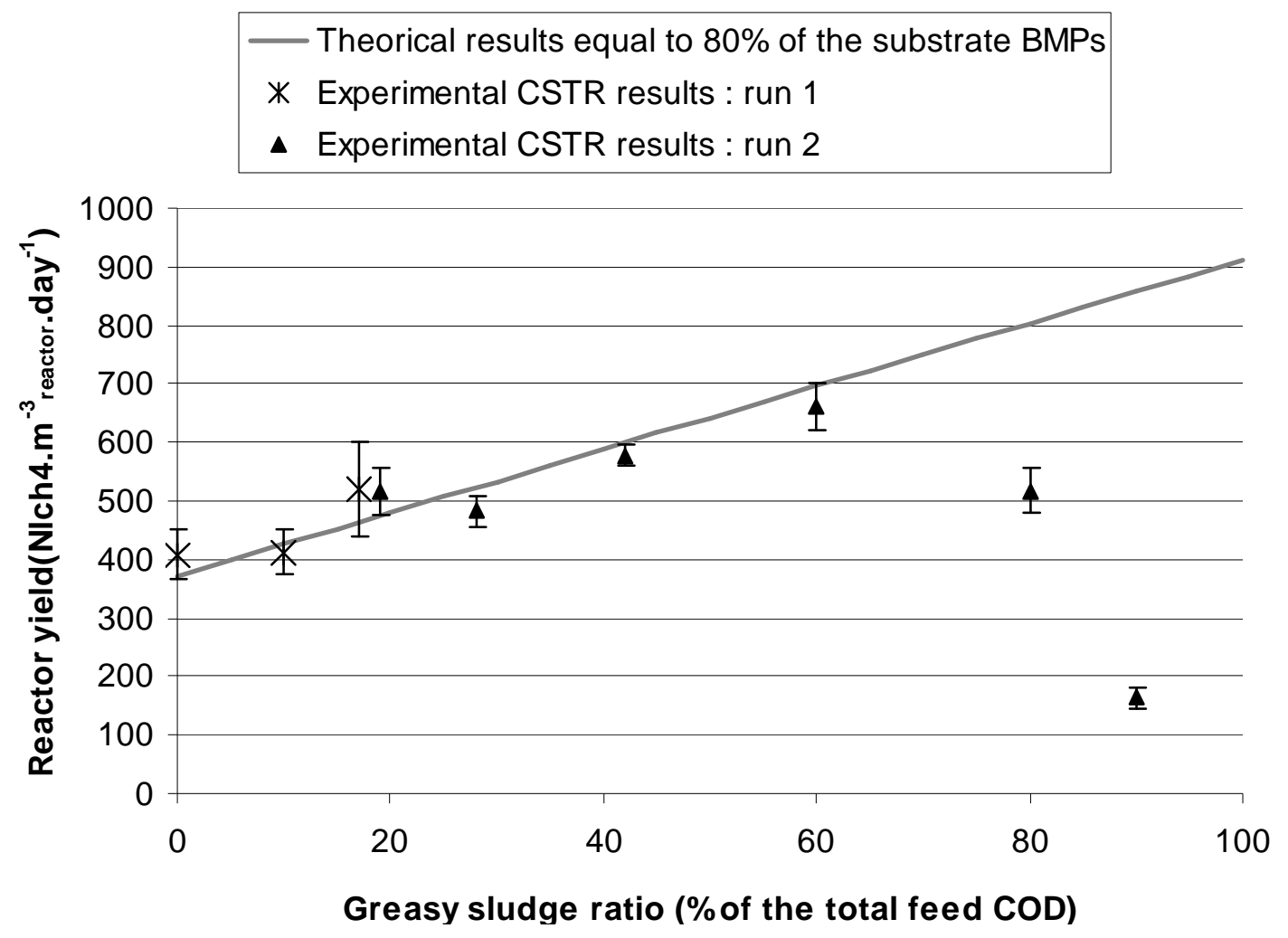

Figure 4: Effect of the greasy sludge ratio on the reactor yield: CSTR versus batch results.

Error bars represent standard deviation on the calculation period.

The reactor yield estimated from batch experiments was calculated as $80 \%$ of the arithmetic sum of the BMP of each substrate. Considering the standard deviation of the experimental CSTR results, batch experiments allowed accurate estimation of the reactor yield as the greasy sludge ratio did not exceed $60 \%$ of the feed COD. Concerning inhibition, in the batch experiments, a greasy sludge ratio of between 20 and 30\% (depending on the inoculum) was sufficient to induce an significant reduction in the degradation kinetics of the mixture of greasy sludge and WAS. In the CSTR experiments, significant consequences of the inhibition were observed with a greasy sludge ratio higher than $60 \%$.

As a result, batch experiments can be considered as an accurate way to estimate the methane production related to co-digestion, if the degradation phenomena are additive. However, batch experiments do not allow determination of the maximum ratio of lipid rich effluent to incorporate for anaerobic digestion of a mixture of substrates. Indeed, in this case, negative substrate interactions observed in the batch experiments were over-estimated. This phenomenon can be explained by the acclimation phenomenon as highlighted by Silvestre et 
al. (2011). Acclimation can occur due to two main phenomena: (1) the growth of biomass able to degrade LCFAs and (2) shifts in biomass populations which increase the number of bacteria acclimated to higher LCFA concentrations in the reactor. Palatsi et al. (2010) demonstrated the predominance of the first phenomenon. Moreover, as demonstrated previously in this study and in the literature (Hwu et al., 1996; Alves et al., 2001; Lalman and Bagley 2002), batch results in terms of inhibitions are strongly dependant on the origin of the inoculum, its physical structure and the operational conditions of the experiment. Modelling could be a useful way to extrapolate batch results in designing data for CSTR co digestion, taking into account specific biomass growth and specific inhibitions.

\section{Conclusion}

CSTR experiments indicated that co-digestion of greasy sludge with WAS is optimal with a greasy sludge ratio of $60 \%$ of the feed COD (lipids representing $31 \%$ of the feed VS). With higher ratios, accumulations of LCFAs (palmitic, stearic and oleic acids) were observed. In batch experiments, a reversible inhibition occurred with a greasy sludge ratio between 20 and $30 \%$ of the feed COD. Hence, batch experiments can predict methane production in a CSTR when the degradation phenomenon are additive (without inhibition). But when inhibitions occur, it is not possible to directly extrapolate batch observations to design data for co-digestion in CSTR.

\section{Acknowledgments}

The authors thank Saur Research and Development for funding this study.

\section{References}

Alatriste-Mondragón, F., Samar, P., Cox, H.H.J., Ahring, B.K., Iranpour, R., 2006. Anaerobic codigestion of municipal, farm, and industrial organic wastes: A survey of recent literature. Water Environment Research. 78 (6), 607-636.

Alves, M.M., Vieira, J.A.M., Pereira, R.M.A., Pereira, M.A., Novais, J.M., Mota, M., 2001. Effects of lipids and oleic acid on biomass development in anaerobic fixed reactors. Part II: oleic acid toxicity and biodegradability. Water Research. 35, 264-270 
Angelidaki, I., Ahring, B.K. 1992. Effects of free long-chain fatty acids on thermophilic anaerobic digestion. Applied Microbiololgy and Biotechnololgy. 37, 808-812.

APHA, 1998. Standard Methods for the Examination of Water and Wastewater, 20th ed. American Public Health Association, Washington DC, USA.

Appels, L., Baeyens, J., Degrève, J., Dewil, R. 2008. Principles and potential of the anaerobic digestion of waste-activated sludge. Progress in Energy and Combustion Science. 34 (6), 755-781

Beccari, M., Majone, M., Torrisi, L. 1998. Two-reactor system with partial phase separation for anaerobic treatment of olive oil mill effluents. Water Science Technology. 38, 5360 .

Broughton, M.J., Thiele, J.H., Birch, E.J., Cohen, A. 1998. Anaerobic batch digestion of sheep tallow. Water Research. 32, 1423-1428.

Carrère, H., Dumas, C., Battimelli, A., Batstone, D.J., Delgenès, J.P., Steyer, J.P., Ferrer, I. 2010. Pretreatment methods to improve sludge anaerobic degradability: A review. Journal of Hazardous Materials. 183 (1-3), 1-15

Chynoweth, D. 1993. Biochemical methane potential of biomass and waste feedstocks. Biomass And Bioenergy. 5 (1), 95-111

Cirne, D.G., Paloumet, X., Björnsson, L., Alves, M.M., Mattiasson, B. 2007. Anaerobic digestion of lipid-rich waste-Effects of lipid concentration. Renewable Energy. 32 (6), 965-975

Davidsson, Å., Lövstedt, C., la Cour Jansen, J., Gruvberger, C., Aspegren, H. 2008. Codigestion of grease trap sludge and sewage sludge. Waste Management. 28 (6), 986-992

Hwu, C-S., Tseng, S.K., Yuan, C.Y., Kulik, Z., Lettinga, G. 1998. Biosorption of long-chain fatty acids in UASB treatment process. Water Research. 32, 1571-1579.

Kabouris, J.C., Tezel, U., Pavlostathis, S.G., Engelmann, M., Dulaney, J., Gillette, R.A., Todd, A.C. 2009. Methane recovery from the anaerobic codigestion of municipal sludge and FOG. Bioresource Technology. 100 (15), 3701-3705.

Knezevic, Z., Mavinic, D.S., Anderson, B.C. 1995. Pilot scale evaluation of anaerobic codigestion of primary and pretreated waste activated sludge. Water Environment Research. 67 (5), 835-841.

Koster, I.W., Cramer, A. 1987. Inhibition of methanogenesis from acetate in granular sludge by long-chain fatty acids. Applied Environmental Microbiology. 53, 403-409.

Lalman, J.A., Bagley, D.M. 2000. Anaerobic degradation and inhibitory effects of linoleic acid. Water Research. 34, 4220-4228.

Lalman, J.A., Bagley, D.M. 2001. Anaerobic degradation and methanogenic inhibitory effects of oleic and stearic acids. Water Research. 35, 2975-2983.

Luostarinen, S., Luste, S., Sillanpää, M. 2009. Increased biogas production at wastewater treatment plants through co-digestion of sewage sludge with grease trap sludge from a meat processing plant. Bioresource Technology. 100 (1), 79-85.

Mata-Alvarez, J., Mace, S., Llabrés, P., 2000. Anaerobic digestion of organic solid wastes. An overview of research achievements and perspectives. Bioresource Technology. 74, 316. 
Palatsi, J., Illa, J., Prenafeta-Boldú, F.X., Laureni, M., Fernandez, B., Angelidaki, I., Flotats, X. 2010. Long-chain fatty acids inhibition and adaptation process in anaerobic thermophilic digestion: Batch tests, microbial community structure and mathematical modelling. Bioresource Technology. 101 (7), 2243-2251.

Parkin, G.F, Owen W.F. 1986. Fundamentals of Anaerobic Digestion of Wastewater Sludges. Journal of Environmental Engineering .12(5), 867-912.

Pereira, M.A., Pires, O.C., Mota, M., Alves, M.M. 2005. Anaerobic biodegradation of Oleic and Palmitic Acids: Evidence of Mass Transfer Limitations Caused by Long Chain Fatty Acid Accumulation onto the Anaerobic Sludge. Biotechnology and Bioengineering. 92(1), 15-23.

Ponsá, S., Gea, T., Sánchez, A. 2011. Anaerobic co-digestion of the organic fraction of municipal solid waste with several pure organic co-substrates. Biosystems Engineering. 108 (4), 352-360.

Rinzema, A., Boone, M., van Knippenberg, K., Lettinga, G. 1994. Bactericidal effect of long chain fatty acids in anaerobic digestion. Water Environment Research. 66, 40-49.

Salminen, E., Rintala, J., Lokshina, L.Ya., Vavilin, V.A., 2000. Anaerobic batch degradation of solid poultry slaughterhouse waste. Water Science and Technology. 41 (3), 33-41

Silvestre, G., Rodríguez-Abalde, A., Fernández, B., Flotats, X., Bonmatí, A. 2011. Biomass adaptation over anaerobic co-digestion of sewage sludge and trapped grease waste. Bioresource Technology. In Press 